\title{
Radiogrammetric Study on the Allometry of Human Digits
}

\author{
Shozo TAKaI and Harumi TeradA \\ Department of Anatomy, School of Medicine, \\ Kitasato University
}

\begin{abstract}
The new idea of "complete isometry" was introduced to study the intercorrelation of the allometric growth of the human pentadactylism. Complete isometry is obtained from both primary and inverse allometric functions and means that two characters studied grow, in a statistical sense, at a completely proportional pace It was manifested that the growth pattern of human digits was grouped into axial and marginal, and the group of the marginal digits grew at a more positive allometric pace than that of axial digits. The biological law of axo-marginal growth gradient was clarified in the human pentadactylate hand.
\end{abstract}

The human pentadactylate hands have been studied for many years from the standpoint of growth and variation. As for the associations between the rates of elongation of the hand bones, Roche \& Hermann (1969) revealed that the communality indices for bones grouped in rays tended to differ considerably between rays, i.e. the indices in boys were highest in the fourth ray and lowest in the first ray, while in girls, the highest indices were in the third ray and the lowest were in either the first or fifth rays. On the other hand, the studies on the variability and correlation within rays for the adult series clarified that the relative variability (coefficients of variation) were greatest in the thumb and the little finger and least in the other fingers, and that the thumb and the little finger had less correlation than the other fingers (LEWENZ \& $\mathrm{WHI}^{-}$ TELEY, 1902). It might lead to the view that the growth and variation of the thumb and the little finger which are situated marginally would differ from those of the other fingers which are located more axially.

The purpose of the present paper is to analyze the interrelation of the linear growth of digits by means of $5 \times 5$ matrices of the simple allometric regression.

\section{MATERIALS AND METHODS}

Materials consisted of radiographs of the right hand of healthy 72 males and 72 females living in Tokyo or its environs. The age of the subjects ranged from 4 to 18 years (Table 1 ). The radiographic investigations were carried out in 1963 and 1964.

With $85 \mathrm{~cm}$ focal distance the central ray was applied at the head of the third metacarpal bone and was radiated in dorsopalmar direction. The finger length in this study represents the sum of the length of three phalangeal bones: proximal, 
Table 1. The number of subjects according to age.

\begin{tabular}{ccc}
\hline Age & Male & Female \\
\hline 4 & 3 & 4 \\
5 & 4 & 4 \\
6 & 3 & 4 \\
7 & 7 & 4 \\
8 & 3 & 2 \\
9 & 7 & 5 \\
10 & 5 & 6 \\
11 & 6 & 5 \\
12 & 3 & 0 \\
13 & 8 & 7 \\
14 & 4 & 5 \\
15 & 5 & 4 \\
16 & 5 & 6 \\
17 & 5 & 6 \\
18 & 4 & 10 \\
\hline & 72 & 72 \\
\hline
\end{tabular}

middle and distal. If the epiphyseal union was not accomplished, the length of each phalanx was measured according to RocHE \& Hermann (1969). And the materials in which the bony epiphysis was not yet appeared were excluded from the present study. Sliding vernier calipers were used for the measurement of each phalanx and the values of finger length were expressed in tenths of millimeters. All statistical calculations were made with the aid of the IBM 360 Model 40-F computer.

\section{RESULTS}

In the first place, the data were plotted on log-log graph papers for any combinations of the two out of five digits (Figs. 1-10). A linear relationship was suggested in all combinations of digits, showing no tendency of curvilinearity. Subsequently, regression $\operatorname{lines,} \log \hat{Y}=\alpha \log X+\log b$, were fitted to these data and the equilibrium constants $(\alpha)$ and initial growth indices (b) were calculated on the basis of a method of least-squares. The equilibrium constants $(\alpha)$, initial growth indices $(b)$ and mean square deviations from regres sion $(\mathrm{S} e)$ are shown in Table 2. Analysis

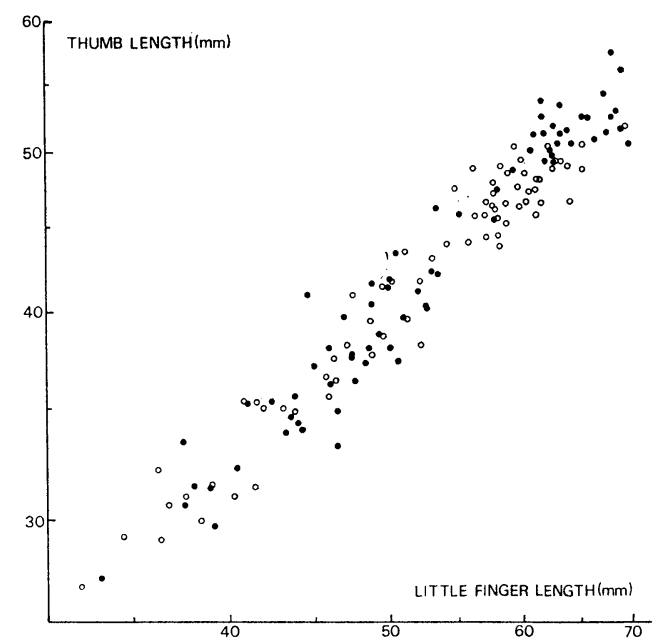

Fig. 1. Scatter diagram of the thumb and the little finger lengths. (solid circle: males, open circle: females)

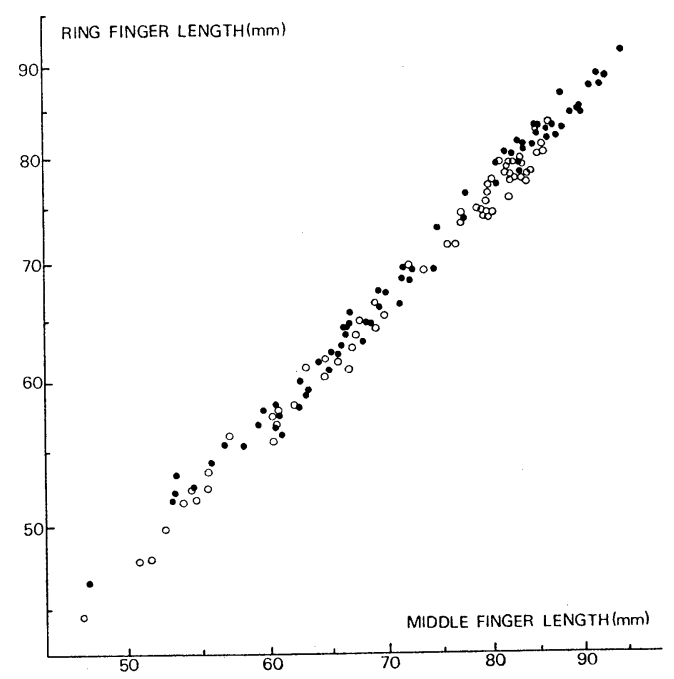

Fig. 2. Scatter diagram of the ring and the middle finger lengths. 


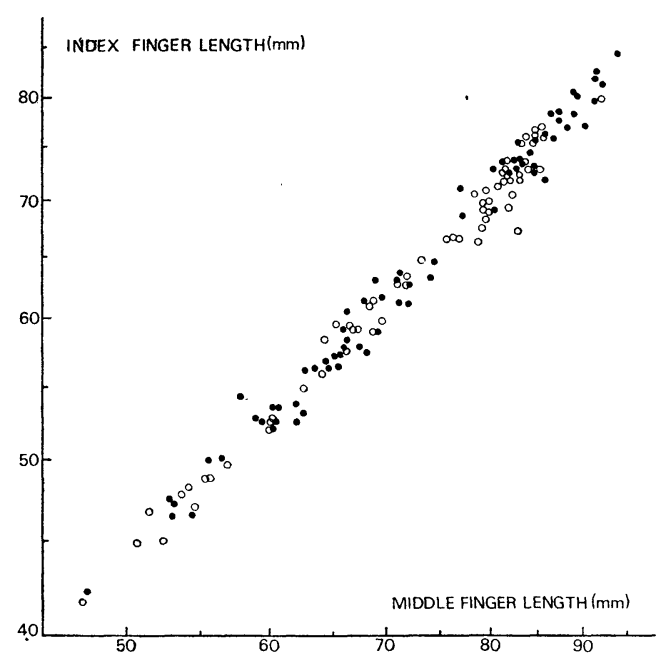

Fig. 3. Scatter diagram of the index and the middle finger lengths.

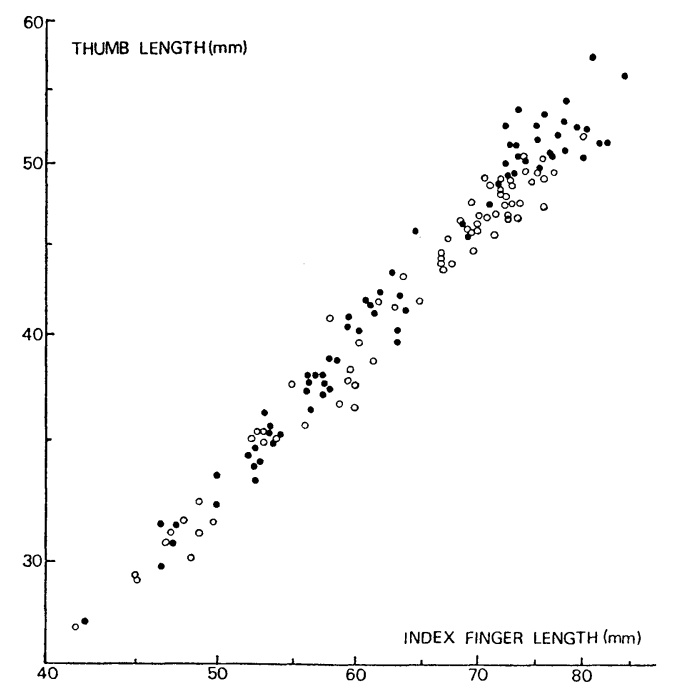

Fig. 4. Scatter diagram of the thumb and the index finger lengths.

of variance showed that all the regression coefficients (equilibrium constants) were statistically significant at $1 \%$ level. This indicates the allometry formula $Y=b X^{\alpha}$ is valid to all combinations of digits.

The large mean square deviations from regression $(\mathrm{Se})$ were found in the allomet-

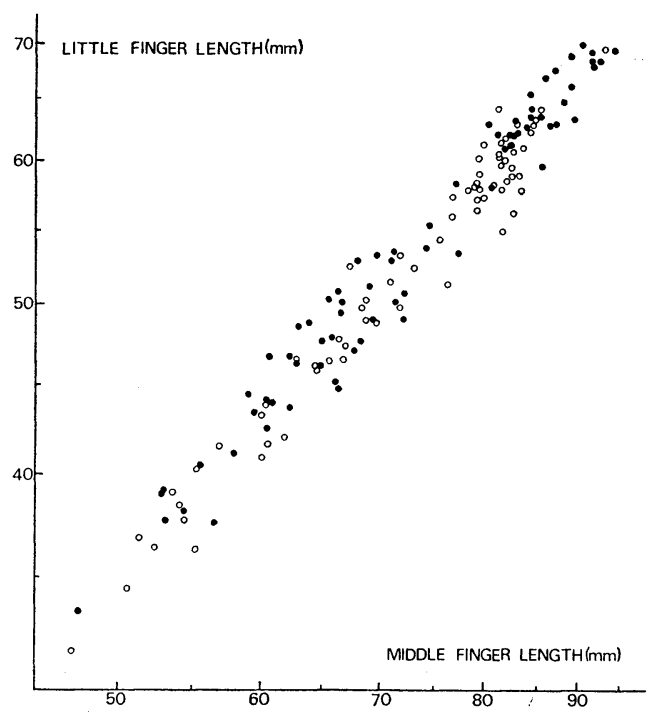

Fig. 5. Scatter diagram of the little and the middle finger lengths.

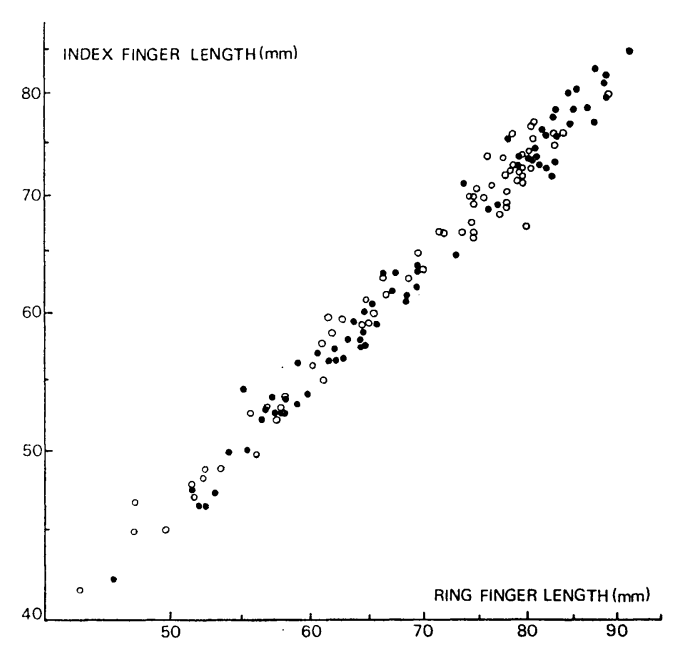

Fig. 6. Scatter diagram of the index and the ring finger lengths.

ric regressions of the thumb length on the little finger length $\left(4.0057 \times 10^{-4}\right.$ in males and $2.7623 \times 10^{-4}$ in females). The deviations are detectable in Fig. 1. Whereas the small deviations from regression were found in the allometric regression of the middle finger on the ring finger $\left(0.5018 \times 10^{-4}\right.$ in 


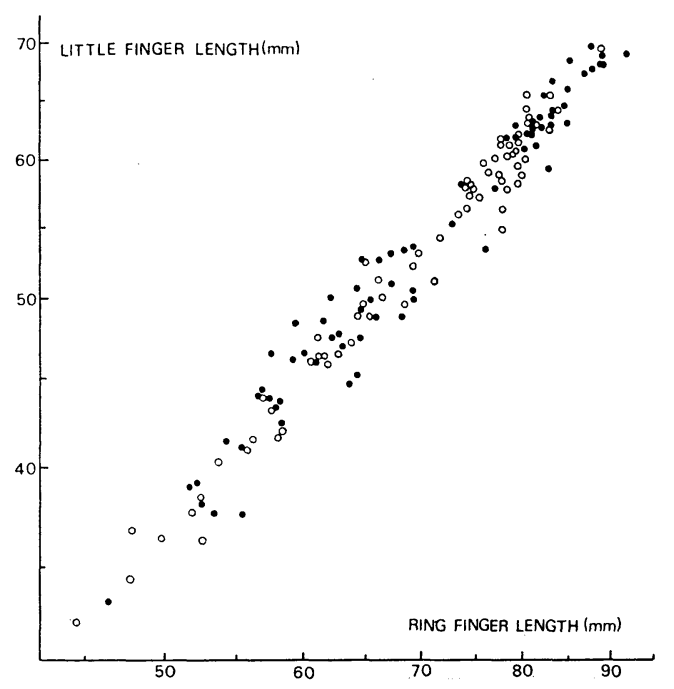

Fig. 7. Scatter diagram of the little and the ring finger lengths.

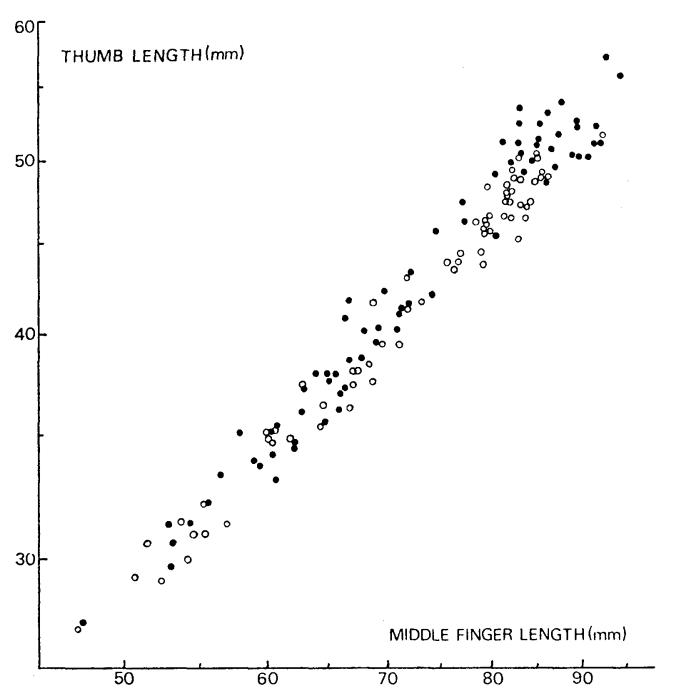

Fig. 8. Scatter diagram of the thumb and the middle finger lengths.

males and $0.5051 \times 10^{-4}$ in females); in that of the ring finger on the middle finger $\left(0.5077 \times 10^{-4}\right.$ in males and $0.5290 \times 10^{-4}$ in females); and in that of the index finger on the middle finger $\left(0.9490 \times 10^{-4}\right.$ in males and $0.7607 \times 10^{-4}$ in females). These de-

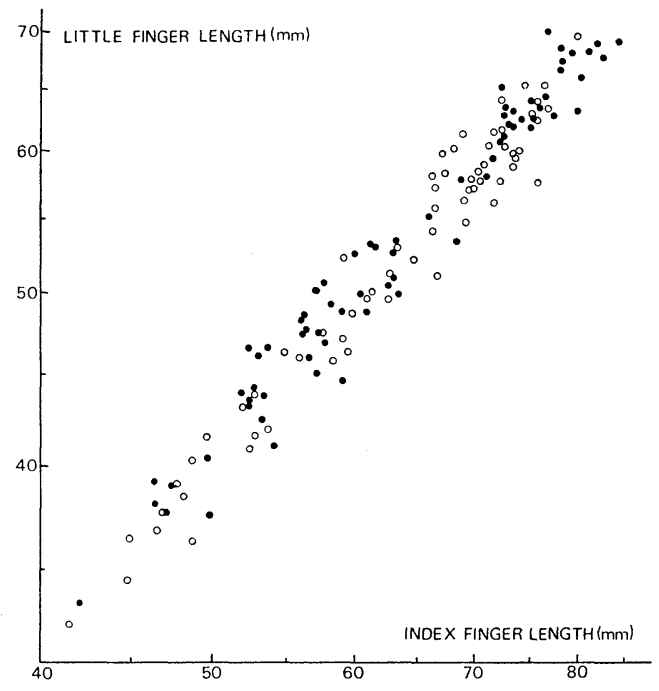

Fig. 9. Scatter diagram of the little and the index finger lengths.

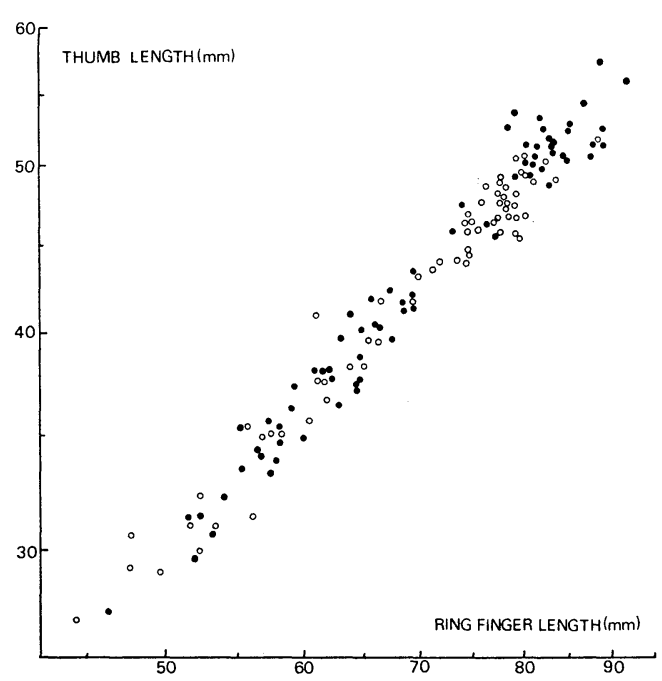

Fig. 10. Scatter diagram of the thumb and the ring finger lengths.

viations are also detectable in Figs. 2 and 3. The sex differences of the mean square deviations from regression were statistically significant at $5 \%$ level for these allometric regressions of the middle finger on the thumb; those of the thumb on the middle 
Table 2. Equilibrium constant $(\alpha)$, initial growth index $(b)$ and mean square deviation from regression $(S e)$ in the allometric regression, $\log \hat{Y}=\alpha \log X+\log b$.

\begin{tabular}{|c|c|c|c|c|c|c|c|}
\hline \multicolumn{2}{|c|}{ Digits } & \multicolumn{3}{|c|}{ Males } & \multicolumn{3}{|c|}{ Females } \\
\hline$X$ & $Y$ & $\alpha$ & $\log b$ & $\mathrm{Se}$ & $\alpha$ & $\log b$ & $\mathrm{Se}$ \\
\hline II & I & 1.04 & -0.2525 & $2.0087 \times 10^{-4}$ & 1.02 & -0.2113 & $1.4297 \times 10^{-4}$ \\
\hline III & I & 1.05 & -0.3290 & 2.5266 & 1.01 & -0.2655 & 1.3544 \\
\hline IV & I & 1.05 & -0.3031 & 2.3335 & 0.99 & -0.1942 & 1.7857 \\
\hline V & I & 0.96 & -0.0220 & 4.0057 & 0.89 & 0.0973 & 2.7623 \\
\hline I & II & 0.93 & 0.2901 & 1.7920 & 0.96 & 0.2506 & 1.3489 \\
\hline III & II & 1.00 & -0.0658 & 0.9490 & 1.00 & -0.0381 & 0.7607 \\
\hline IV & II & 1.00 & -0.0368 & 1.0336 & 0.96 & -0.0310 & 1.1375 \\
\hline V & II & 0.91 & 0.2283 & 2.3464 & 0.87 & 0.3156 & 2.0613 \\
\hline$I$ & III & 0.91 & 0.3726 & 2.1962 & 0.96 & 0.3024 & 1.2853 \\
\hline II & III & 0.98 & 0.0946 & 0.9247 & 1.00 & 0.0658 & 0.7651 \\
\hline IV & III & 0.99 & 0.0356 & 0.5018 & 0.97 & 0.0719 & 0.5051 \\
\hline V & III & 0.90 & 0.3019 & 2.0390 & 0.87 & 0.3634 & 1.7271 \\
\hline I & IV & 0.92 & 0.3448 & 2.0523 & 0.98 & 0.2516 & 1.7746 \\
\hline II & IV & 0.98 & 0.0688 & 1.0190 & 1.01 & 0.0099 & 1.1982 \\
\hline III & IN & 1.00 & -0.0194 & 0.5077 & 1.02 & -0.0549 & 0.5290 \\
\hline V & IV & 0.91 & 0.2785 & 2.2405 & 0.90 & 0.3006 & 1.3427 \\
\hline I & $\mathrm{V}$ & 0.98 & 0.1271 & 4.1122 & 1.07 & -0.0156 & 3.3384 \\
\hline II & $\mathrm{V}$ & 1.05 & -0.1706 & 2.7001 & 1.11 & -0.2798 & 2.6404 \\
\hline III & $\mathrm{V}$ & 1.07 & -0.2604 & 2.4081 & 1.11 & -0.3447 & 2.1995 \\
\hline IV & V & 1.06 & -0.2279 & 2.6153 & 1.09 & -0.2839 & 1.6329 \\
\hline
\end{tabular}

finger; those of the ring finger on the little finger; and those of the little finger on the ring finger, respectively.

The majority of the equilibrium constants ( $\alpha$ ) falls between 0.9 and 1.1. In males, the mean values of the allometric regressions of the thumb and of the little finger on other four digits have higher equilibrium constants of 1.05 and 1.03 , respectively. Those of index, middle and ring fingers have lower constants of $0.96,0.95$ and 0.95 , respectively. In females slight different trends can be seen. The allometric regression coefficients or the equilibrium constants of the little finger on the other four digits show the greatest values of 1.10, while those of the index and middle fingers represent the least value of 0.95. And the regressions of the thumb and of the ring finger show the intermediate value of 0.98 . The analysis of covariance revealed that the equilibrium constants of the little finger on the thumb showed sex differences in favor of females.

The initial growth index $(b)$ has no biological significance since it is dependent partly on the mean and partly on the equilibrium constant (SHImizu, 1959 \& Lavelle, 1973). Any considerations have not been made herein on the initial growth index.

\section{DISCUSSIONS}

The purpose of the present study is to 
consider how the five digits grow correlatively in the human pentadactylate hand. And the new idea of "complete isometry" is introduced to access the problem. A correlation analysis provides two regression lines in the ordinal bivariate data, i.e. one for the most probable value of $Y$ corresponding to a given value of $X$ and the other conversely for the most probable value of $X$ corresponding to a chosen value of $Y$. In general, these two lines are differently drawn because the correlation coefficient is rarely 1.00. Accordingly, when both the primary $(\hat{Y}=f(X))$ and the inverse $(\hat{X}=g(Y))$ allometric regression equations are statistically recognized to have the equilibrium constants of 1.00 , the term "complete isometry" is used in this study. This would imply that the two

Table 3. Results of the allometry test.

\begin{tabular}{|c|c|c|c|c|c|}
\hline \multicolumn{6}{|c|}{ Male } \\
\hline$X_{X}^{Y}$ & I & II & III & IV & V \\
\hline I & 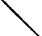 & - & - & - & 土 \\
\hline II & \pm & 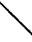 & \pm & \pm & 土 \\
\hline III & \pm & \pm & 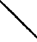 & \pm & + \\
\hline IV & + & \pm & \pm & & + \\
\hline V & \pm & - & - & - & \\
\hline
\end{tabular}

Female
\begin{tabular}{|c|c|c|c|c|c|}
\hline$X Y$ & I & II & III & IV & V \\
\hline I & & - & - & \pm & + \\
\hline II & \pm & & \pm & \pm & + \\
\hline III & \pm & \pm & & \pm & + \\
\hline IV & \pm & - & - & & + \\
\hline $\mathrm{V}$ & - & - & - & - & \\
\hline
\end{tabular}

+ : positive allometry, \pm : isometry, - : negative allometry. digits concerned grow each other at a completely proportional pace.

Table 3 summarized the results of the test to examine whether the allometry formulae are isometry or not. In males the complete isometry was statistically recognized in the regressions among the index, middle and ring fingers and in that between the thumb and the little finger. These facts suggest that the index, middle and ring fingers which are located in the axial part of the hand have the same growth rate, and that the thumb and the little finger arranged in the medial and lateral margins of the hand grow at a similar pace. As is naturally expected, these consideration may deduce that the growth of digits is different between the axial II, III, IV digits and marginal I, V. Furthermore, although the growth of the thumb against that of the index and middle fingers, and the growth of the little finger against that of index finger do not show statistically significant positive allometry $(\alpha=1.04,1.05$ and 1.05 , respectively), all the inverse allometric relations are statistically recognized as significantly negative. This would lead to the view that the marginal digits grow at a quicker pace than the axial ones and that this is true at the reverse relation.

In females slight different trends can be seen. The complete isometry is recognized solely between the index and middle fingers and between the thumb and the ring finger. This seems to suggest that the different modes of growth would proceed in the following three groups: (1) the marginal little finger; (2) axial index and middle 
fingers; and (3) the thumb and the ring finger. The little finger grows at a quicker pace than the others, while the group of index and middle fingers grows at a slower pace than the group of the thumb and the ring finger. The growth of the group of the thumb and the ring finger shows the isometry against the index and middle fingers, but does not follow the positive allometry. Therefore, in females it can be said that the growth rates of digits in terms of allometry are greater in the following sequence: the little finger; the thumb and ring finger; and index and middle fingers. From these facts it seems reasonable to conclude that the marginal digits do not necessarily grow parallel with the axial ones, and that there may be sex differences in the allometric pattern of finger growth.

In addition, ReEve \& Huxley (1947) indicated that the growth-gradient pattern was most clearly demonstrated in the allometric study. They established in the crustaceans the law of antero-posterior development in the growth ratio of successive bilateral appendages and revealed that the growth ratio usually declined anteroposteriorly. In analogy with the above mentioned facts, it might be probable that the relative growth-gradient would effect on the human pentadactylate hand. In other words, the growth center lies in the axial group of fingers and the growth rate increases toward axo-marginal direction.

In the present study, the tendency that the five digits are classified into the marginal and axial groups, was also recognized in terms of complete isometry as well as of the mean square deviations from regression or equilibrium constants. Anyhow, further studies are necessary to verify the validity in the grouping of the growth of human digits into the marginal and axial patterns.

\section{SUMMARY}

The interrelationship of the linear growth of digits was studied radiogrammetrically by means of $5 \times 5$ matrices of the allometric regressions in 72 males and 72 females aged 4 to 18 years.

The allometry formula, $Y=b X^{\alpha}$, is valid for all combinations of digits, since analy. sis of variance showed the significance of the equilibrium constants $(\alpha)$.

The large mean square deviations from regression and the higher equilibrium constants were found in the allometric regressions of the thumb and of the little finger on other digits.

In terms of complete isometry, two groups of digits: axial II, III, IV and marginal I, V were established in males, while three groups : axial II, III ; marginal $\mathrm{V}$; the other I, IV were constituted in females. The marginal digits showed quicker growth rate than the axial digits in males. The growth rates were increased in the order of axial II, III; the other I, IV; marginal $\mathrm{V}$ in females. From the facts described above, it was assumed that the law of axo-marginal development was present in the human pentadactylate hand.

\section{ACKNOWLEDGEMENT}

The authors would like to acknowledge assistance in the statistical analysis by $\mathrm{Mr}$. 
S. Ninomiya of the Kitasato Total Information System, Kitasato University, and also to acknowledge assistance in the collection of useful references by Miss M. HAyAshi of the Medical Library, Kitasato University.

\section{REFERENCES}

Boyes, J. H., 1964: Bunnel's Surgery of the Hand. 4th Ed, 24-54. Lippincott, Philadelphia $\&$ Toronto.

Hewit T, D., 1963: Pattern of correlations in the skeleton of the growing hand. Ann. Hum. Genet., 27 : 157-168.

Kato, T., Hasue, M. \& Sato, M., 1955: On the linear growth of the metacarpal and phalangeal bones in infants. Nichidai Igaku Zasshi, 14: 1531-1537 (in Japanese).

Kimura, K. \& Hatтori, K., 1968 : Radiological studies of the development of hand bones growth of the third digital and metacarpal bones. J. Anthrop. Soc. Nippon, 76:18-26 (in
Japanese with Englich summary).

LAvelle, C. L. B., 1973: The relationship between jaw, arm and leg size in three ethnic groups. Am. J. Anat., 136: 259-263.

Lewenz, M. A. \& Whiteley, M. A., 1902: Data for the problem of evolution in man. A second study of the variability and correlation of the hand. Biometrika, 1: 345-360.

Reeve, E. C. R. \& Huxley, J.S., 1947: Some problems in the study of allometric growth. In: Essays on growth and form presented to D'Arcy Wentworth Thompson. Ed. by Le Gros Clark, W. E. \& Medawar, P. B., 121156. Oxford Univ. Press, London.

Roche, A. F. \& Hermann, R. F., 1969: Associations between the rates of elongation of the short bones of the hand. Am. J. Phys. Anthrop., 32 : 83-88.

ShimizU, M., 1959: Relative Growth. Kyodo Isho Shuppansha, Tokyo (Japanese text).

SPRENT, P., 1972: The mathematics of size and shape. Biometrics, $28: 23-37$.

(Received June 30,1973)

\section{$\mathrm{X}$ 線計测によるヒトの手指の相対成長について}

\section{高井省三・寺田春水 \\ 北里大学医学部解剖学教室}

4 18才の男女各72名の右手X線フィルムを用い，相対成長の立場から各指の長さの相互関係を分析した。 指長としては各指節骨長の合計值が用いられている。対数変換された 5 指の計測值のうちの 2 指ずつを組合せ た散布図は直線性を予測させたので, 最小自乘法によって一次回帰式, $\log \hat{Y}=\alpha \log X+\log b$ を求めた。平 衡定数 ( $\alpha$ ) の有意性検定はアロメトリ一式, $Y=b X^{\alpha}$ がすべての組合せに適用できるととを示した。

母指長の小指長へのアロメトリ一回帰の残差 $(S e)$ は男女ともに大きく, 一方, 中指の薬指への回帰, 薬指 の中指への回帰，示指の中指への回帰の残差は男女と屯に小さい。平衡定数 $(\alpha)$ の大多数は $0.9 \sim 1.1$ の間に

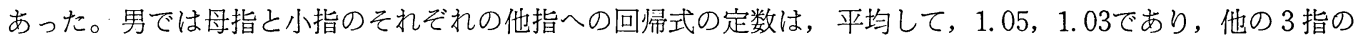
それは0.95 0.96であった。女では小指：1.10，母指之薬指：0.98，示指と中指：0.95の定数をあつ。始原成 長係数 $(b)$ は生物学的意味をむたないのでててでは論じられていない。

男女各20の回帰式のうち，もとの関数之逆関数の両者が同時に推計学的に 1.00 のをあつ之認められる時 に，ての 2 形質の間の発育を完全等成長 (complete isometry) と呼び, てれによって 5 指の発育パターン の分類を試みた。男では母指と小指の間，示指・中指・薬指の間に完全等成長が認められた。女では母指と薬 指の間, 示指と中指の間に完全等成長が認められた。つまり，男では辺縁㑡にある母指と小指のグループと軸 側䎲ある示指, 中指, 薬指のグループの 2 群が分類され, また女では辺縁側の小指, 軸側の示指と中指, なら びに母指と薬指の 3 群が分類される。男女とも各グループの発育テンポの優劣関係は, 辺縁側群が軸側群より あ優成長するととが知られた。とのととからヒトの手の各指の発育には，軸側部から辺縁側部へと高くなる成 長階梯の存在が考えられる。 